\title{
FUTURE-CLIMATE EXPERIMENTS ON THE INTENSITY AND STORM SURGE OF TYPHOON SANBA (2012)
}

\author{
Masaya Toyoda ${ }^{1}$ Jun Yoshino $^{1}$ and Tomonao Kobayashi ${ }^{1}$
}

\begin{abstract}
In this study, present- and future-climate experiments using the high-resolution typhoon and storm surge models were conducted on Typhoon Sanba (2012) causing a storm surge disaster in Kyushu Island, Japan. Typhoon intensity at the decaying stage was increased in every global warming scenario. The average changes in typhoon intensity were $-5.5 \mathrm{hPa}$ in the 2030s and $-10.4 \mathrm{hPa}$ in the 2090s. In addition, the largest future change occurred in September in the 2090s. The future storm surge at Oura Port, Saga Prefecture, Japan was 1.3 times larger than that under the present climate. The results suggest that the storm surge disasters on Kyushu Island will be more severe in the end of the 21 st century, and appropriate mitigation strategies should be developed for this region.
\end{abstract}

Keywords: Typhoon Sanba, storm surge, climate change, pseudo-global warming downscaling

\section{INTRODUCTION}

Increase in air temperature, sea surface temperature, and ocean heat storage is considered to vastly impact the characteristics of tropical cyclones (i.e., hurricane, typhoon, and cyclone) (Wada et al. 2007; IPCC 2013; Lin et al. 2013; Trenberth et al. 2018). These changes of parameters raise concerns about potential changes in the intensity of tropical cyclones (Lin et al. 2014; Knutson et al. 2015; Tsuboki et al. 2015; Balaguru et al. 2016). In addition, future changes in tropical cyclones will impacts storm surges and high waves that are associated with them (Nakajo et al. 2013; Mori et al. 2016; Mori and Takemi 2016). Therefore, it is one of the problems that should be addressed for the Pacific Rim countries prone to coastal disasters.

Recently, much research on future changes in typhoon intensity, storm surges, and high waves has been conducted. However, future-climate projections derived from the general circulation models (GCMs) used in those studies remains large uncertainties. Therefore, the recent Fifth Assessment Report (AR5) by the Intergovernmental Panel on Climate Change (IPCC) has yet to determine conclusively whether the future climate change could influence the future typhoon intensity (IPCC 2013).

Against such a background of uncertainty, dynamical downscaling technique is used as a method of quantitative assessment for the impact of global warming on tropical cyclones and the associated storm surges (Knutson et al. 2015; Yoshino et al. 2015). Takayabu (2015) investigated the impacts of global warming on typhoon intensity and storm surge by comparing past climate with present climate using this technique. In addition, the authors (Toyoda et al. 2017) evaluated the differences in the impact of global

\footnotetext{
${ }^{1}$ Graduate school of Engineering, Gifu University, 1-1 Yanagido, Gifu 501-1193, Japan
} 


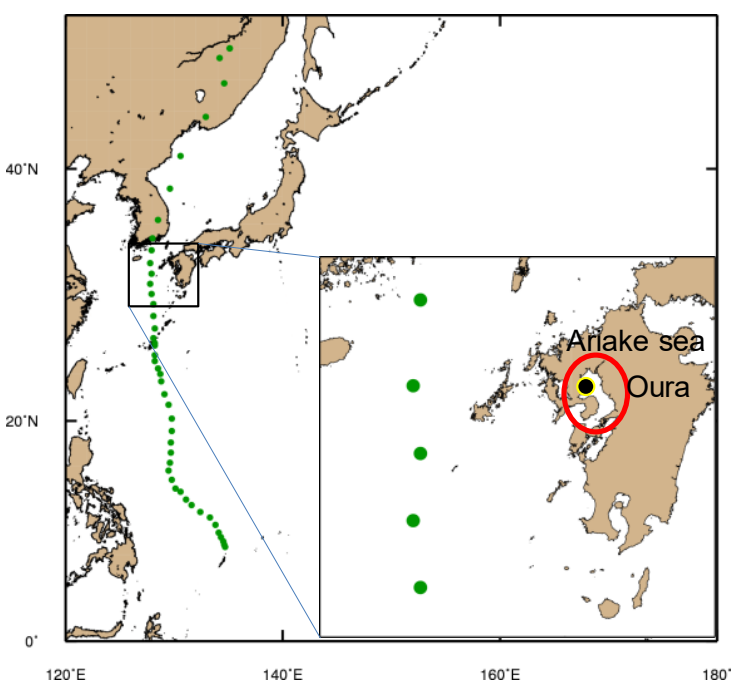

Figure 1. Track of Typhoon Sanba (2012) investigated in this study.

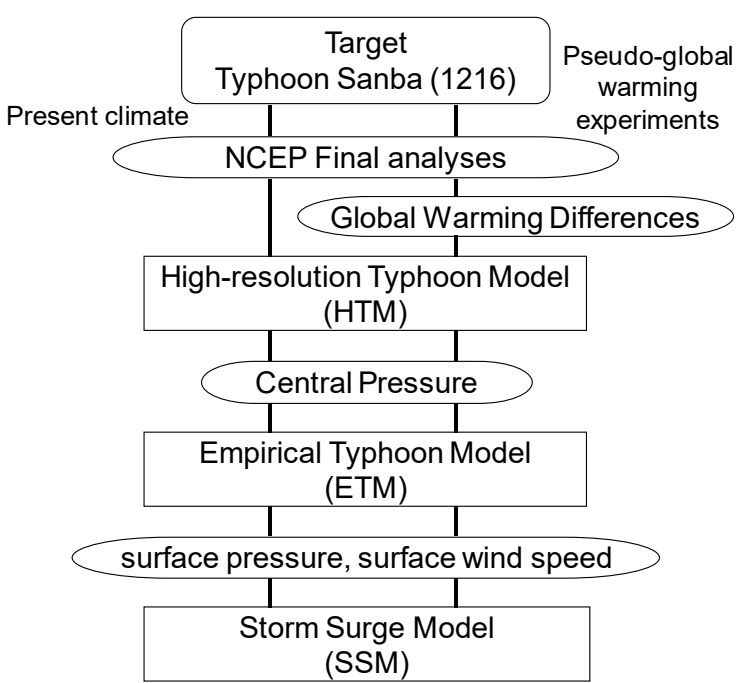

Figure 2. A schematic flow of computational framework.

warming on the intensity of typhoons in different regions (e.g., tropical and subtropical areas), for two cases of typhoons: Typhoon Haiyan (2013) landed in the Philippines and Typhoon Melor (2009) landed in Japan. Those results showed that the future change in the intensity of the typhoon in the subtropical area is larger than that in the tropical area. However, these were only two cases; hence, is no guarantee that the same conclusion will be made for other typhoon cases, and an accumulation of cases is necessary.

In this research, we conduct a present-climate experiment (CNTRL) and ensemble pseudo-global warming experiments (PGWEs) on the intensity of Typhoon Sanba (2012) and its associated storm surge. The goals of this manuscript are to evaluate the impacts of global warming differences (GWDs) on typhoon intensity and storm surge, and to estimate the sensitivities for different months (August, September, and October) in the typhoon season.

\section{MODEL DESCRIPTIONS}

\section{A typhoon case focused in this study}

In this research, Typhoon Sanba (2012) was selected for investigating the future change in typhoon intensity and storm surge (Figure 1). Sanba was a super typhoon, the intensity of which reached a central pressure of $900 \mathrm{hPa}$ with a maximum wind speed of $55 \mathrm{~m} / \mathrm{s}$ in the mature stage, and it traveled toward the north along the western coast of Kyushu Island, Japan, causing storm surge disasters around the coastal areas on 17 September 2012 (Japan Meteorological Agency 2017). The maximum sea level was $3.60 \mathrm{~m}$ and the maximum sea-level anomaly reached $1.04 \mathrm{~m}$ as observed at Oura Port, Saga Prefecture, Japan. This typhoon brought about a wide variety of damages in West Japan (e.g., damage to residents, sediment 
Table 1. Computational settings of parameters used in the high-resolution typhoon model.

\begin{tabular}{|c|c|c|c|}
\hline & Domain (D1) & Domain (D2) & Domain (D3) \\
\hline TC Case & \multicolumn{3}{|c|}{ Typhoon Sanba (2012) } \\
\hline Period & \multicolumn{3}{|c|}{ 0000UTC,11 Sep. 2012 - 0000UTC, 18 Sep. 2012} \\
\hline Horizontal resolution & $27 \mathrm{~km}$ & $9 \mathrm{~km}$ & $3 \mathrm{~km}$ \\
\hline Horizontal grids & $298 \times 349$ & $91 \times 91$ & $91 \times 91$ \\
\hline Time step & $90 \mathrm{sec}$ & $30 \mathrm{sec}$ & $10 \mathrm{sec}$ \\
\hline Vertical resolution & \multicolumn{3}{|c|}{24 layers $(1000-70 \mathrm{hPa})$} \\
\hline Initialization & $\begin{array}{c}\text { NCEP Final Analyses } \\
\left(1^{\circ} \times 1^{\circ}\right) \\
\text { each } 6 \text { houers } \\
\end{array}$ & D1 (27km) & $\mathrm{D} 2(9 \mathrm{~km})$ \\
\hline Movable nest & Off & On & On \\
\hline Typhoon bogus & $\begin{array}{l}\text { Wind speed } 17.2 \mathrm{~m} / \mathrm{s} \\
\text { Rankin's vortex }\end{array}$ & Off & Off \\
\hline Nudging (4DDA) & On & Off & Off \\
\hline Cumulus convection scheme & Kain-Fritsch cumulus & Off & Off \\
\hline Cloud microphysics scheme & \multicolumn{3}{|c|}{ Reisner graupel } \\
\hline PBL scheme & \multicolumn{3}{|c|}{ Mellor-Yamada Level2.5 Eta PBL } \\
\hline Radiation scheme & \multicolumn{3}{|c|}{ Cloud radiation } \\
\hline Land surface scheme & \multicolumn{3}{|c|}{ 5-layer soil } \\
\hline Ocean mixed layer scheme & \multicolumn{3}{|c|}{ Shade and Emanuel(1999) } \\
\hline Sea spray scheme & \multicolumn{3}{|c|}{ Fairall et al.(1994) } \\
\hline Dissipative heating scheme & \multicolumn{3}{|c|}{ Jin et al.(2007) } \\
\hline
\end{tabular}

Table 2. Computational settings of the parameters used in the storm surge model.

\begin{tabular}{c|c}
\hline Target Typhoon & Typhoon Sanba (2012) \\
\hline Calculation time & 0300UTC,16 Sep.2012 - 0300UTC,17 Sep.2012 \\
\hline Horizontal resolution & $1 \mathrm{~km}$ \\
\hline Time step & $1 \mathrm{sec}$ \\
\hline Vertical resolution & 1 layer \\
\hline \multirow{2}{*}{\begin{tabular}{c} 
Seabed topography \\
\cline { 2 - 2 }
\end{tabular}} & Coastline: USGS Landuse (30sec $\times 30 \mathrm{sec})$ \\
\hline Initial condition & zero (u=0,v=0,h=0) \\
\hline $\begin{array}{c}\text { Meteorological } \\
\text { external force }\end{array}$ & Central pressures from HTM \\
\hline $\begin{array}{c}\text { Boundary condition } \\
\text { Moving speed (lon.) }\end{array}$ & Off \\
\hline Moving speed (lat.) & $-0.008^{\circ} / \mathrm{h}$ \\
\hline
\end{tabular}

disasters, flood damage, blackouts, and traffic problems). One of the biggest reasons for the extent of the storm surge damage is believed to be that the typhoon occurred during a high spring tide in September (Japan Meteorological Agency 2012).

\section{High-resolution typhoon model (HTM)}

The high-resolution typhoon model (HTM) was used to simulate the intensity changes in the overall life cycles of two super typhoons. HTM is based on the mesoscale meteorological model PSU/NCAR MM5 (Dudhia 1993). MM5 is a three-dimensional, nonhydrostatic, fully compressible, cloud-resolving atmospheric model used to reproduce mesoscale and local-scale meteorological phenomena. The automatic movable nesting technique was introduced into MM5 to efficiently reproduce the high-resolution structure near the center of an intense typhoon from the genesis stage to the dissipation stage (Yoshino et al. 2012). Additionally, several kinds of physical parameterizations (e.g., the ocean mixed layer, dissipative heating, and sea-spray processes) were implemented into MM5 to accurately express realistic typhoon intensity and structure (Yoshino et al. 2012). The triply nested computational domains used in this study have horizontalgrid spacings of $27 \mathrm{~km}$ (D1), $9 \mathrm{~km}$ (D2), and $3 \mathrm{~km}$ (D3). The movable nesting technique was applied to both D2 and D3. The four-dimensional data-assimilation technique (also called as nudging) was utilized for only D1 to gradually assimilate the gridded analyses into the typhoon environment. The initial and boundary conditions for the HTM were derived from the NCEP Final Analyses FNL (temperature, geopotential height, east-west wind velocity, north-south wind velocity, relative humidity, sea-level pressure, and ground surface temperature). 
Table 3. 6 types of global warming scenarios used in this study.

\begin{tabular}{c}
\hline Global warming scenarios \\
\hline 2030 s (Aug.) \\
\hline 2030 s (Sep.) \\
\hline 2030 s (Oct.) \\
\hline 2090 s (Aug.) \\
\hline 2090 s (Sep.) \\
\hline 2090 s (Oct.) \\
\hline CNTRL (Sep.)
\end{tabular}

Table 4. 15 types of general circulation models used in this study.

\begin{tabular}{|c|c|c|}
\hline Name & Development facilities & Resolution \\
\hline BCCR_BCM2_0 & Bjerknes Centre for Climate Research, Norway & $1.9 \times 1.9$ \\
\hline CNRM_CM3 & $\begin{array}{l}\text { Météo-France/Centre National de Recherches Météorologiques, } \\
\text { France }\end{array}$ & $1.9 \times 1.9$ \\
\hline CSIRO_MK3_0 & \multirow{2}{*}{-CSIRO Atmospheric Research,Australia } & \multirow{2}{*}{$1.9 \times 1.9$} \\
\hline CSIRO_MK3_5 & & \\
\hline GFDL_CM2_0 & \multirow{2}{*}{$\begin{array}{l}\text { U.S. Dept. of Commerce/NOAAGGeophysical Fluid Dynamics } \\
\text { Laboratory, USA }\end{array}$} & \multirow{2}{*}{$2.0 \times 2.5$} \\
\hline GFDL_CM2_1 & & \\
\hline IAP_FGOALS1_0_G & $\begin{array}{l}\text { Institute of Atmospheric Physics, Chinese Academy of Sciemces, } \\
\text { China }\end{array}$ & $2.8 \times 2.8$ \\
\hline INMCM3_0 & Institute for Numerical Mathematics, Russia & $4.0 \times 5.0$ \\
\hline MIROC3_2_HIRES & \multirow{2}{*}{$\begin{array}{l}\text { Center for Climate System Research (University of Tokyo), } \\
\text { - National Institute for Environmental Studies, and Frontier } \\
\text { s Research Center for Global Change (JAMSTEC), Japan }\end{array}$} & $1.1 \times 1.1$ \\
\hline MIROC3_2_MEDRES & & $2.8 \times 2.8$ \\
\hline MPI_ECHAM5 & Max Planck Institute for Meteorology, Germany & $1.9 \times 1.9$ \\
\hline MRI_CGCM2_3_2A & Meteorological Research Institute, Japan & $2.8 \times 2.8$ \\
\hline NCAR_CCSM3_0 & National Center for Atmospheric Research, USA & $1.4 \times 1.4$ \\
\hline UKMO_HadCM3 & \multirow{2}{*}{$\begin{array}{l}\text { Hadley Centre for Climate Prediction and Research/Met Office, } \\
\text { UK }\end{array}$} & $2.75 \times 3.75$ \\
\hline UKMO_HadGEM1 & & $1.25 \times 1.875$ \\
\hline
\end{tabular}

\section{Empirical typhoon model (ETM) and storm surge model (SSM)}

Storm surge changes substantially with only a slight difference in the typhoon track. In order to avoid an error of storm surge due to a slight difference in typhoon track in the HTM, the atmospheric fields (surface wind speed and surface pressure) in a typhoon were reanalyzed in this study by using an empirical typhoon model (ETM) that can be controlled by the typhoon position and intensity (central pressures) simulated by the HTM (Mitsuta 1997). Then the typhoon position data ingested into the ETM were substituted by the best track data obtained from the Japan Meteorological Agency (JMA). Using this fixed typhoon track for the storm surge model, it was expected that the global warming impacts of typhoon intensity changes on storm surge could be evaluated effectively.

ETM comprises two algebraic equations in a horizontal two-dimensional plane: a pressure-distribution equation and a gradient wind equation. The pressure distribution in a typhoon was estimated by the Myers formula (Myers 1954). The gradient balance equation was used for the calculation of wind fields in the typhoon's core, considering the balance between the pressure gradient force, the Coriolis force, and the centrifugal force. The Blaton formula is used to consider the effect of typhoon movement on the wind fields. The Goldberg-Mohn friction formula is assumed to include the surface frictional effect on the wind fields. Then, the inflow angle between the geostrophic wind vectors and the surface wind vector is set to $10^{\circ}$, which is typical of the marine environment.

For the computational settings of the ETM, the radius of maximum wind speed was set to $80 \mathrm{~km}$, which was estimated by the previous study for Sanba (Nakajo et al. 2013). The typhoon movement vectors were defined by linear approximation by connecting two points between 1200 UTC 6 September -1200 UTC 7 September 2012, derived from the JMA best track. Thus the vector components for Sanba were set 
to $0.008^{\circ} \mathrm{h}^{-1}$ in the longitudinal direction and $0.296^{\circ} \mathrm{h}^{-1}$ in the latitudinal direction. The other configuration settings are as shown in Table 1 and used by the previous study (Toyoda et al. 2017).

The storm surge model (SSM) used in this study comprises the nonlinear longwave equations system, which predicts 2-dimensional distributions of the sea-level anomaly and ocean-current vectors. The typhoon atmospheric fields estimated by the ETM were input as the boundary conditions at 15 min intervals. The computational domains of the SSM were set with a horizontal resolution of $1 \mathrm{~km}$ located around the target port: Oura Port in Saga Prefecture, Japan. The requisite topography data were obtained from the global earth surface relief dataset ETOPO1 with a horizontal-grid resolution of 1 min, produced by the National Ocean and Atmospheric Administration (NOAA). We used the global land use dataset with a horizontal-grid resolution of $30 \mathrm{~s}$, provided by the U.S. Geological Survey (USGS). The SSM computation was performed for 1 day ( $24 \mathrm{~h}$ ) from 0300 UTC 16 September 2012 to 0300 UTC 17 September 2012 as shown in Table 2.

\section{Present and future-climate experiments}

A number of numerical experiments were performed according to the computational flow shown in Figure 2 using the HTM, ETM, and SSM. First, a present-climate experiment for Sanba (hereafter CNTRL) was conducted using NCEP Final Analyses (FNL) as the initial and boundary conditions. Additionally, future-climate experiments were also conducted by using the technique of pseudo-global warming experiments (PGWEs) (Kimura and Kitoh, 2007). By estimating the differences between the CNTRL and PGWEs, we can quantify the future changes in typhoon intensity and storm surge that we can expect to accompany global warming. The initial and boundary conditions for the PGWEs are created by adding to FNL the differences of the ten-year-averaged monthly mean fields (e.g., temperature, sea surface temperature, geopotential height, east-west wind speed, north-south wind speed, and relative humidity),

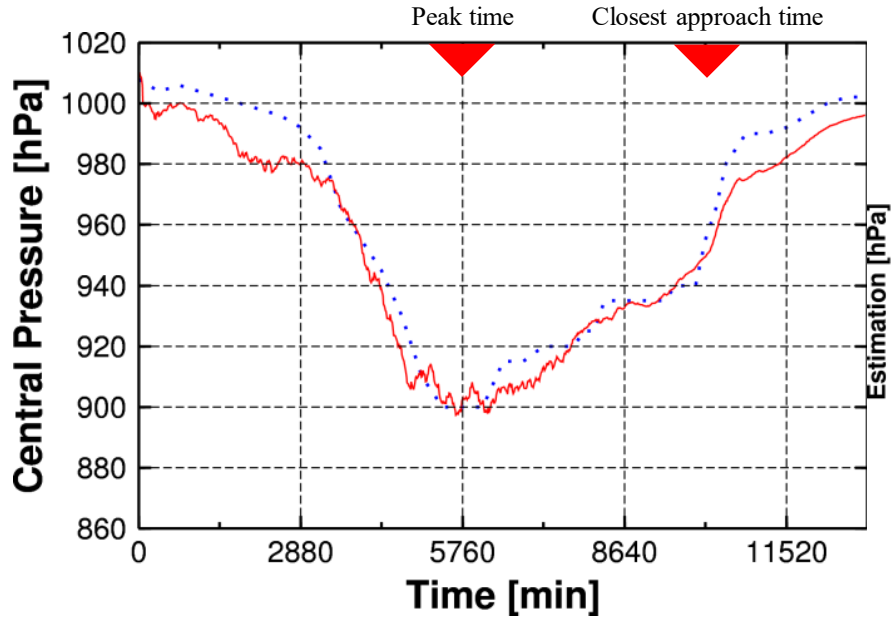

Figure 3. Time series of the central pressure of Typhoon Sanba simulated by the HTM (red line) and derived by the JMA best track (blue dotted line).

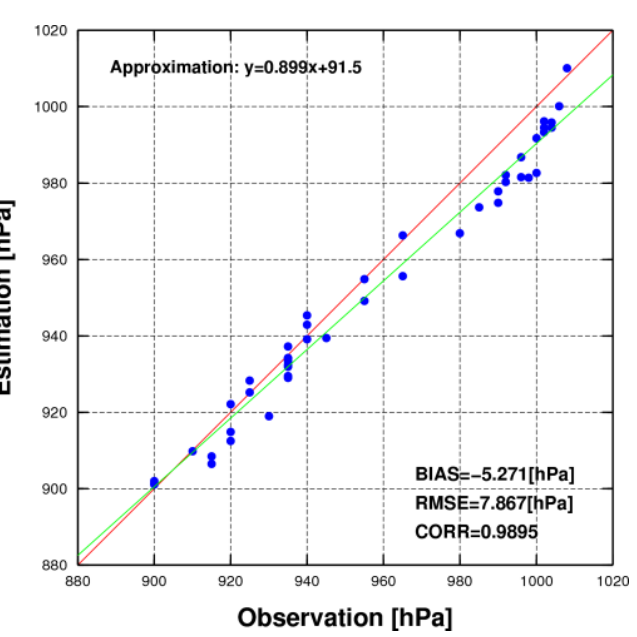

Figure 4. Verification of accuracy for the central pressure of Typhoon Sanba. 


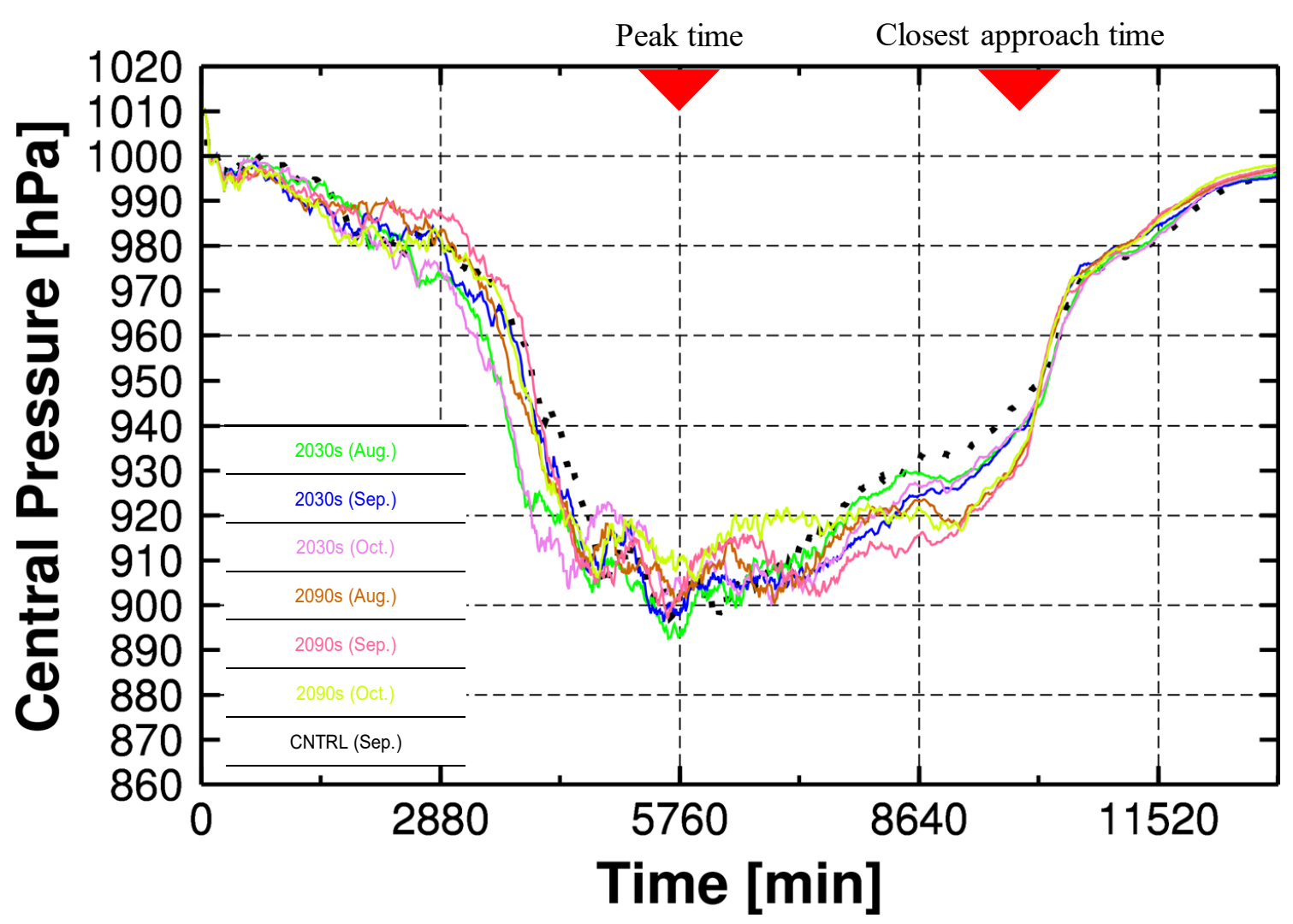

Figure 5. Time series of the central pressure of Typhoon Sanba simulated by PGWEs (black dotted line: CNTRL, the colors of the solid lines correspond to the scenarios listed in Table 3.

a which herein re referred to as the global warming differences (GWDs) obtained from different GCMs with different ages. Then, the calculation types are divided into three separate months (August, September, and October) for two decadal periods (2030s and 2090s) as shown in Table 3. The GWDs were derived from the ensemble averages of 15 GCMs under the A1B scenario in the CMIP3 multi-model ensemble. Those 15 GCMs are listed in Table 4. Comparing the results among different GWDs, it is expected that the future change of the typhoon intensity and its storm surge may be evaluated at different ages at different seasons.

\section{RESULTS AND DISCUSSION}

\section{Present-climate experiment (CNTRL) for the typhoon intensity and storm surge}

First, we will discuss the results of the present-climate experiment for Sanba (Figure 3 and Table 5) before discussing the main subject, namely the results of the PGWEs. According to the JMA best track, the observed central pressures at peak time (5760 min) and at closest approach time to Oura Port (9960 min) were $900 \mathrm{hPa}$ and $940 \mathrm{hPa}$, respectively; the HTM results were $902.0 \mathrm{hPa}$ and $946.9 \mathrm{hPa}$, respectively (Table 5). In addition, an accuracy verification was conducted with the JMA best track as the observed 
values for central pressure throughout the overall life cycle of Sanba (Figure 4); the bias error was -5.3 $\mathrm{hPa}$, the root mean square error was $7.87 \mathrm{hPa}$, and the correlation coefficient was 0.99 , so the HTM results can be said to have reproduced the observed changes with very high accuracy. The result of the storm surge at Oura Port from the ETM and SSM was $0.95 \mathrm{~m}$ as the maximum sea-level anomaly, which was quite close to the observed value (1.04 m) (Table 5). The HTM can reproduce the mature intensity of Super Typhoon Sanba and the storm surge results were generated with high accuracy, such that it is thought that a certain precision is guaranteed also for the PGWEs discussed in the next section.

\section{Pseudo-global warming experiments (PGWEs) for the intensity}

Next, the results of the PGWEs for Sanba will be discussed (Figure 5 and Table 5). The future changes in typhoon intensity can be discussed by dividing into two stages: mature stage at the peak time (5760 $\mathrm{min})$ and decaying stage at the closest approach time to Kyushu Island (9960 min). The typhoon intensity at the mature stage increased by an average of $-2.9 \mathrm{hPa}$ in the $2030 \mathrm{~s}$, and it decreased by an average of $+2.5 \mathrm{hPa}$ in the 2090s. On the other hand, at the closest approach time to Kyushu Island, the typhoon intensity increased in any global warming scenarios. The typhoon intensity at the decaying stage increased by an average of $-5.5 \mathrm{hPa}$ in the $2030 \mathrm{~s}$, and the biggest future change occurred in September $(-6.2 \mathrm{hPa})$. Typhoon intensity increased by an average of $-10.4 \mathrm{hPa}$ in the $2090 \mathrm{~s}$, and the biggest future change was also the result for September $(-12.0 \mathrm{hPa})$. Figure 6 shows the GWDs of sea surface temperature between the 2030s and 2090s in each month (August, September, and October). With respect to the differences in typhoon intensity between the mature and decaying stages, the difference in sea surface temperature rise is considered to have a large impact. According to the GWDs of sea surface temperature in September when Sanba occurred, the sea surface temperature increases in both the 2030s and 2090s. In addition, the increase tends to be larger in the mid-latitudes than in the tropics, and the difference is largest in the 2090s. Therefore, it is estimated that the future change became larger for the closest approach time to Kyushu Island than that for the peak time. The small positive or negative changes of the typhoon intensity under the future climate might be caused by the fact that the air temperature in the upper troposphere (300

(a)

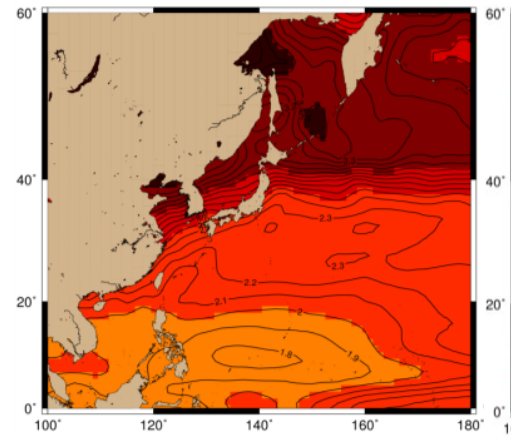

(b)

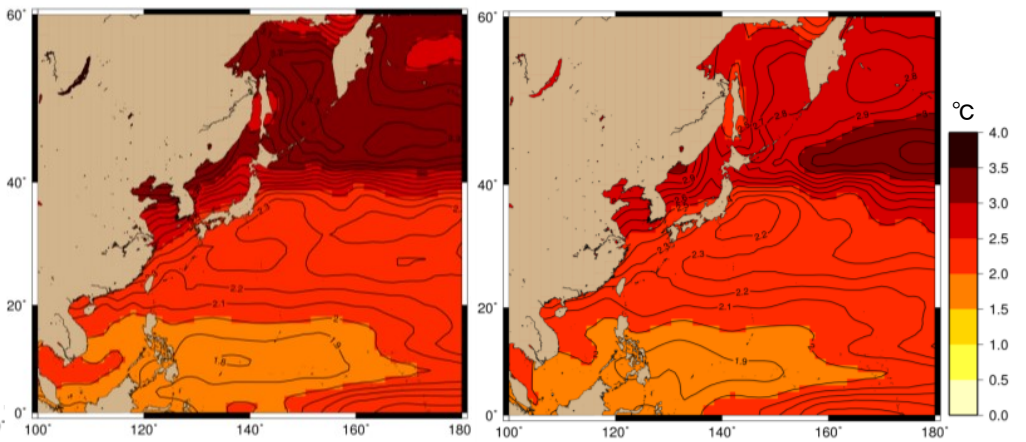

Figure 6. Global warming differences in sea surface temperature between the 2030s and 2090s:

(a) August, (b) September, and (c)October. 
$\mathrm{hPa}$ ) could rise more than the sea surface temperature, and the stratification in the free troposphere is more stable under the future climate than under the present climate. Figure 7 shows the GWDs of air temperature in the upper troposphere $(300 \mathrm{hPa})$ in September between the 2000s and 2090s. According to Bister and Emanuel (2002), the peak intensity of a steady-state typhoon, which is proportional to the ratio of sea surface temperature to tropopause temperature, is shown below.

$$
\left|V_{\text {max }}\right|^{2}=\frac{T_{S}}{T_{o}} \frac{C_{k}}{C_{D}}\left[C A P E^{*}-C A P E\right]_{m}
$$

where $V_{\max }$ is the maximum wind speed; $T_{S}$ is the sea surface temperature; $T_{O}$ is the tropopause temperature; $C_{k}$ and $C_{D}$ are the entropy of sea level and the exchange coefficient of momentum, respectively; $C A P E^{*}$ is the latent effective potential energy of lifting saturated air at the sea surface; and $C A P E$ is the latent effective potential energy of lifting wet air in the boundary layer, both of which are evaluated based on the vertical profile of the atmosphere. Focusing on the right side of Eq. (1), the rise of sea surface temperature strengthens typhoon intensity, but the rise of air temperature in the upper troposphere weakens typhoon intensity. Sea surface temperature will tend to rise with an increase of about +2 degree $\mathrm{C}$ in both the tropics and midlatitudes, and air temperature will tend to rise overall as a result of global warming, but with an increase of +4.8 degree $\mathrm{C}$ in the tropics and an increase of +4.1 degree $\mathrm{C}$ in the midlatitudes, it is clear that the atmosphere in the tropics will experience greater warming. As a result, the increase of typhoon intensity is considered to be inhibited at the tropics where Sanba was well developed

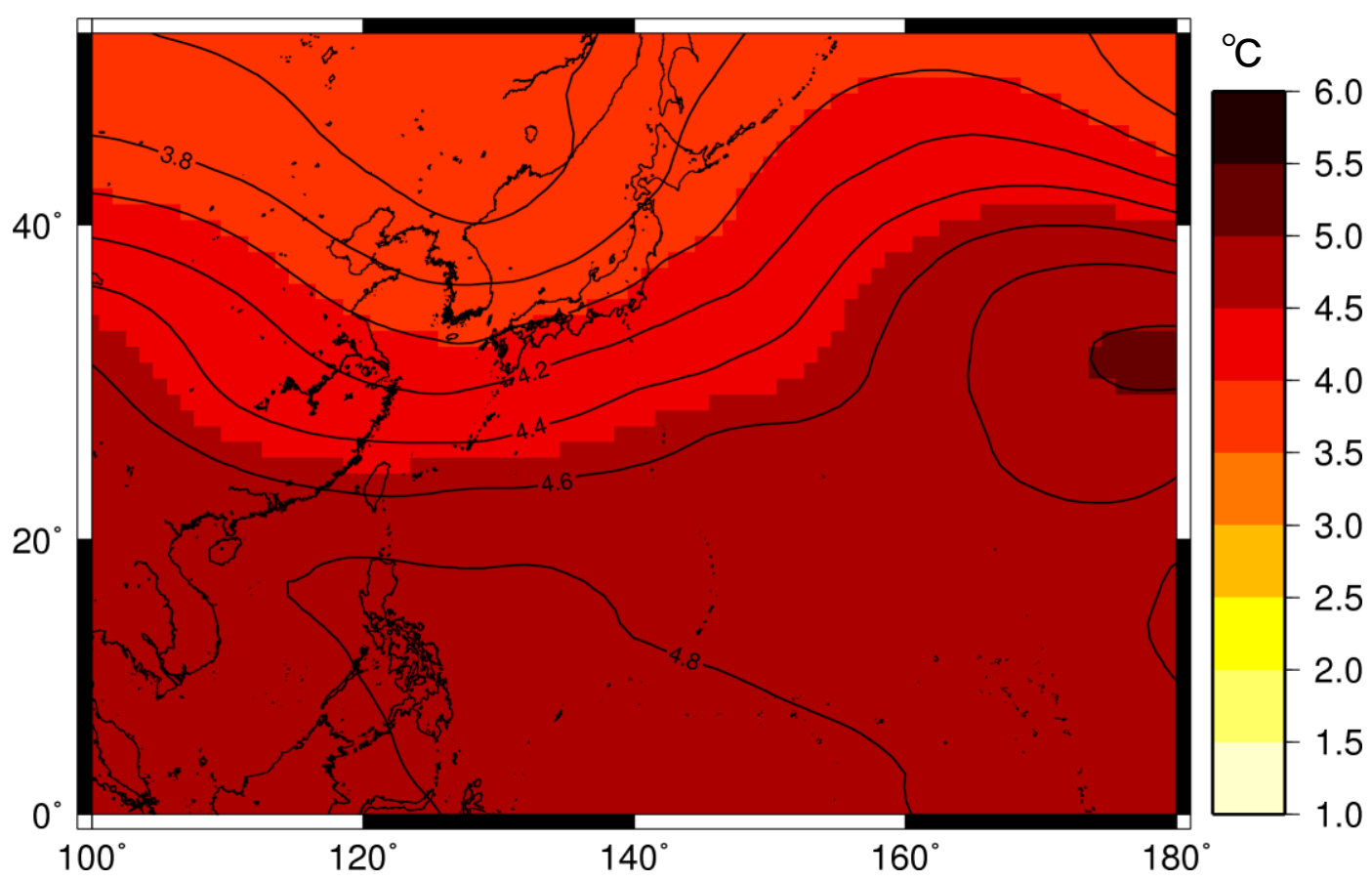

Figure 7. Global warming difference of air temperature at $300 \mathrm{hPa}$ in September between the 2000s and 2090s. 
Table 5. Summary of the results of the CNTRL and PGWEs.

\begin{tabular}{|c|c|c|c|c|c|c|c|c|}
\hline & \multicolumn{2}{|c|}{ present climate } & \multicolumn{3}{|c|}{ near-future climate } & \multicolumn{3}{|c|}{ future climate } \\
\hline & $\begin{array}{l}\text { Obs. } \\
\text { (Sep.) }\end{array}$ & $\begin{array}{c}\text { CNTRL } \\
\text { (Sep.) }\end{array}$ & $\begin{array}{l}\text { 2030s } \\
\text { (Aug.) }\end{array}$ & $\begin{array}{l}\text { 2030s } \\
\text { (Sep.) }\end{array}$ & $\begin{array}{l}\text { 2030s } \\
\text { (Oct.) }\end{array}$ & $\begin{array}{l}\text { 2090s } \\
\text { (Aug.) }\end{array}$ & $\begin{array}{l}\text { 2090s } \\
\text { (Sep.) }\end{array}$ & $\begin{array}{l}\text { 2090s } \\
\text { (Oct.) }\end{array}$ \\
\hline $\begin{array}{l}\text { Central pressure } \\
\text { at } 5760 \text { min } \\
\text { (Future cahnge) }\end{array}$ & $900 \mathrm{hPa}$ & 902.0hPa & $\begin{array}{l}\text { 893.0hPa } \\
(-9.0 \mathrm{hPa})\end{array}$ & $\begin{array}{l}897.7 \mathrm{hPa} \\
(-4.3 \mathrm{hPa})\end{array}$ & $\begin{array}{l}906.5 \mathrm{hPa} \\
(+4.5 \mathrm{hPa})\end{array}$ & $\begin{array}{l}902.9 \mathrm{hPa} \\
(+0.9 \mathrm{hPa})\end{array}$ & $\begin{array}{l}900.7 \mathrm{hPa} \\
(-1.3 \mathrm{hPa})\end{array}$ & $\begin{array}{l}909.9 \mathrm{hPa} \\
(+7.9 \mathrm{hPa})\end{array}$ \\
\hline $\begin{array}{l}\text { Central pressure } \\
\text { at } 9960 \text { min } \\
\text { (Future change) }\end{array}$ & $940 \mathrm{hPa}$ & $946.9 \mathrm{hPa}$ & $\begin{array}{l}941.2 \mathrm{hPa} \\
(-5.7 \mathrm{hPa})\end{array}$ & $\begin{array}{l}940.7 \mathrm{hPa} \\
(-6.2 \mathrm{hPa})\end{array}$ & $\begin{array}{l}942.3 \mathrm{hPa} \\
(-4.6 \mathrm{hPa})\end{array}$ & $\begin{array}{l}937.1 \mathrm{hPa} \\
(-9.8 \mathrm{hPa})\end{array}$ & $\begin{array}{c}934.9 \mathrm{hPa} \\
(-12 \mathrm{hPa})\end{array}$ & $\begin{array}{l}937.4 \mathrm{hPa} \\
(-9.5 \mathrm{hPa})\end{array}$ \\
\hline $\begin{array}{l}\text { Maximum sea level } \\
\text { anomaly at } 9960 \mathrm{~min} \\
\text { (Future change) }\end{array}$ & $1.04 \mathrm{~m}$ & $0.95 \mathrm{~m}$ & $\begin{array}{c}1.08 \mathrm{~m} \\
(+0.13 \mathrm{~m})\end{array}$ & $\begin{array}{c}1.09 \mathrm{~m} \\
(+0.14 \mathrm{~m})\end{array}$ & $\begin{array}{c}1.07 \mathrm{~m} \\
(+0.12 \mathrm{~m})\end{array}$ & $\begin{array}{c}1.23 \mathrm{~m} \\
(+0.28 \mathrm{~m})\end{array}$ & $\begin{array}{c}1.28 \mathrm{~m} \\
(+0.33 \mathrm{~m})\end{array}$ & $\begin{array}{c}1.21 \mathrm{~m} \\
(+0.26 \mathrm{~m})\end{array}$ \\
\hline
\end{tabular}

in the mature stage (Bister and Emanuel 1998; Yoshino et al. 2012). According to the results of the PGWEs, typhoon intensity at the peak time is greatly affected by global warming when using the GWDs of August and September; the peak intensity of the super typhoon occurring in the typhoon season tends to be stronger under the future climates. In addition, all of the cases showed that typhoon intensity will tend to increase at the closest approach time to Kyushu Island regardless of the GWDs used. Between August and October is the period during which most of the typhoon attacks to Japan occur in any given year, so there is concern that typhoon disasters under the future climate and other associated coastal disasters will be enormous.

\section{Pseudo-global warming experiments (PGWEs) for the storm surge}

Finally, we will compare the storm surge at Oura Port, Saga Prefecture, Japan caused by a Sanba-like typhoon between the present and future climates (Table 5). By increasing typhoon intensity at the closest approach time to Kyushu Island (9960 min), storm surge under the future climate was larger than that under the present climate in all of the cases. The average future changes for the $2030 \mathrm{~s}$ and $2090 \mathrm{~s}$ are $+0.13 \mathrm{~m}$ and $+0.29 \mathrm{~m}$, respectively. Comparing the average future change in maximum sea-level anomaly between the 2030s and 2090s show increases by 1.1 times and 1.3 times, respectively. The increases in the storm surge (maximum sea-level anomaly) under the future climate scenarios are quite large compared with the present climate. In addition, the largest future change in storm surge is in the result for September in the 2090s $(1.28 \mathrm{~m})$, wherein the maximum sea-level anomaly increases by approximately $35 \%$ over that of the present climate (Table 5). Therefore, the future storm surge caused by typhoons may have a tendency to increase under the global warming. In addition, it is revealed that the storm surge using the GWDs for September 
are larger than those for August and October.

\section{CONCLUSION}

In this research, ensemble pseudo-global warming experiments were performed for Super Typhoon Sanba (2012) and its storm surge at Oura Port, Saga Prefecture, Japan. The numerical simulations were performed by setting the ten-year-averaged monthly mean fields in August, September, and October (3 different months) in the 2030s and 2090s (2 different ages). The typhoon intensity increased at the time of the closest approach to Kyushu Island in both the 2030s and 2090s, and it was shown that the month with the largest increase in intensity due to global warming was September. In addition, in the storm surge results using future typhoon intensity, the maximum sea-level anomaly was shown to increase as a result of the increasing typhoon intensity under the future climate. It was the result for September that showed the biggest future change, and its maximum sea-level anomaly increased by about $35 \%$ from the present climate. It became clear that typhoon intensity at the closest approach to Kyushu Island during the typhoon season (August, September, and October) will tend to increase under the future climate, and the associated storm surge will also increase. September is the month when most of the typhoon landings occur in Japan, and it is also the time with the highest astronomical tide in a year, so there are concerns that typhoon disasters and coastal disasters caused by the typhoon disasters will be enormous.

\section{ACKNOWLEDGMENT}

This study was supported by JSPS Research Fellow (No.17J04771) and JSPS KAKENHI Grant (18H01542).

\section{REFERENCES}

Balaguru K., D.R. Judi, and L.R. Leung. 2016. Future hurricane storm surge risk for the U.S. gulf and Florida coasts based on projections of thermodynamic potential intensity, Climate Change, Vol. 138, pp. $99-110$

Bister, M. and K.A. Emanuel 1998. Dissipative heating and hurricane intensity, Atmos.Phys., 65, pp.233240.

Bister, M. and K. A. Emanuel. 2002. Low frequency variability of tropical cyclone potential intensity. 1. Interannual to interdecadal variability, J. Geophys. Res., Vol. 107, No. D24, 4801

Dudhia J. 1993. A nonhydrostatic version of the Penn State-NCAR mesoscale model: Validation test and simulation of an Atlantic cyclone and cold front, Mon. Wea. Rev., Vol.121, pp.1493-1513

IPCC.2013. Climate Change 2013 The Physical Science Basis, Cambridge University Press, 1535p.

Japan Meteorological Agency. 2017. Statistical data of Typhoons, http://www.data.jma.go.jp/fcd/yoho/typhoon/statis-tics/index.html 
Japan Meteorological Agency. 2012. Heavy rains / wind storms, High waves / storm surge due to Typhoon No.16 and atmospheric instability, Meteorological cases that brought about disasters (1989 - current year)

Kimura. F., and A. Kitoh. 2007. Downscaling by pseudo global warming method, The Final Report of ICCAP

Knutson T.R., J.J. Sirutis, and M. Zhao. 2015. Global projection of intense tropical cyclone activity for the late twenty-first century from dynamical downscaling of CMIP5/RCP4.5 scenarios, Journal of Climate, Vol.28, No.18, pp.7203-7224

Lin I-I., G. J. Goni, J. A. Knaff, C. Forbes, and M. M. Ali. 2013. Ocean heat content for tropical cyclone intensity forecasting and its impact on storm surge, Nat Hazards, Vol.66, pp.1481-1500

Lin, I-I., I.-F. Pun., and C.-C. Lien. 2014. "Category-6" supertyphoon Haiyan in global warming hiatus: Contribution from subsurface ocean warming, Geophysical Research Letters, Vol.41, pp.8547-8553

Misuta Y. 1997. Prediction of typhoon wind damages, ANNUALS OF Disas. Prev. Rs. Inst., Kyoto Univ., No.40, A, pp. 47-61

Mori N., M. Kjerland, S. Nakajo, Y. Shibutani, and T. Shimura. 2016. Impact assessment of climate change on coastal hazards in Japan, Hydrological Research Letters, Vol. 10 (3), pp.101-105

Mori N., and T. Takemi. 2016. Impact assessment of coastal hazards due to future changes of tropical cyclones in the North Pacific Ocean, Weather and Climate Extremes, Vol. 11, pp.53-69

Myers, V.A. 1954. Characteristics of United States hurricanes pertinent to levee design for lake Okeechobee, Florida. Hydro-Meteorological Report of U.S. Weather Bureau, 32, pp.1-106

Nakajo S., S.Y. Kim, N. Mori, T. Yasuda, H. Mase, and F. Yamada. 2013. Event attribution of storm surge by using stochastic tropical cyclone model and observation data -basic study of worst-case scenario of tropical cyclone for Yatsushiro sea-, JSCE B2 (Coastal Engineering), Vol.69, No.2 (in Japanese), pp. I_366-I_370

Takayabu, I., K. Hibino, H. Sasaki, H. Shiogama, N. Mori, Y. Shibutani, and T. Takemi. 2015. Climate change effects on the worst-case storm surge: A case study of Typhoon Haiyan, Environmental Research Letters, Vol.10, No.6

Toyoda M., Yoshino J. and Kobayashi T. 2017. Comparison of future change and its uncertainty on typhoon intensity between Typhoon Haiyan (2013) and Typhoon Melor (2009), JSCE B2 (Coastal Engineering), Vol. 73, No.2 (in Japanese), pp. I_217-I_222

Trenberth K.E., L. Cheng, P. Jacobs, Y. Zhang, and J. Fasullo. 2018. Hurricane Harvey links to ocean heat content and climate change adaptation, Earth's Future, Vol.6, Issue 5, pp.730-744

Tsuboki K., M. Yoshioka, T. Shinoda, M. Kato, S. Kanada and A. Kitoh. 2015. Future increase of supertyphoon intensity associated with climate change, Geophysical Research Letters, Vol.42, pp.646652 ,

Yoshino J., S. Arakawa, M. Toyoda, and T. Kobayashi. 2015. Intercomparison of global warming scenarios 
for typhoon intensity change using a High-Resolution Typhoon Model, JSCE B2 (Coastal Engineering), Vol.71, No.2 (in Japanese), pp. I_1519-I_1524,

Yoshino J., J. STRACHAN, P. L. VIDALE 2012. Numerical simulations of the life cycle of super typhoon with high-resolution and high-efficiency, JSCE B2 (Coastal Engineering), Vol.68, No.2 (in Japanese), pp.I_1211-I_1215

Wada A., and N. Usui. 2007. Importance of tropical cyclone heat potential for tropical cyclone intensity and intensification in the western north pacific, Journal of Oceanography, Vol.63, pp.427-447 